\title{
Application of Surfagon and Ketaprofen for increasing fertility and preventing embryonic death in cows after insemination
}

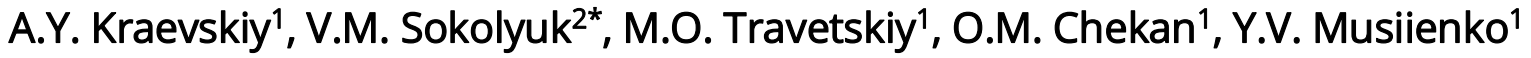 \\ ${ }^{1}$ Sumy National Agrarian University, 160 Kondratieva Str, Sumy, 40021, Sumy, Ukraine \\ ${ }^{2}$ Zhytomyr National Agroecological University, Staryy bulvar, 7, Zhytomyr, 10008, Ukraine \\ *Corresponding author E-mail: vmsokoluk@gmail.com
}

Received: 18.08.2020. Accepted 21.09.2020

\begin{abstract}
Nowadays only $30-50 \%$ of inseminated cows actually calve and the majority of pregnancy loses happens during the first $2-3$ weeks after insemination. Fertility rate of heifers and cows with average milk production is from $90 \%$ to $100 \%$, but in high producing animals that are influenced by stress, such rate can be reduced to $80 \%$. Our experimental researches were conducted in conditions of dairy farms of Poltava and Kharkiv regions of Ukraine in summer of 2020. Estrus synchronizing in cows was started from 50-60 days after calving in Summer time. To prevent Infectious Rinotracheitis, Viral Diarrhea, Parainfluenza 3 in dairy herds cows were vaccinated with polyvalent vaccinations usually before or at the beginning of dry period. Before estrus synchronization trans-rectal sonographic examination was done in all cows to determine condition of uterus and ovaries. During the trial the herd of cows was divided in two groups depending on length of period from calving to estrus synchronizing. In the first group were cows up to 90 days after calving, in the second group - 91 and more days. We registered that Estrus synchronization accordingly to OVSYNCH protocol in 50-90 days (first group) and 91 and more days (second group) after the calving and using Surfagon on day 5 after insemination promote an increasing of cows fertility in the second group on $5.8 \%$ compare to control. At the same time combined using of Surfagon on 5-th and Ainil on 11-th day after insemination in cows of first group promotes their fertility on 7.5\% compare to control animals of this group, and in the second group this increased on $12.6 \%$. At the time of repeated pregnancy diagnostic of cows in 60-65 days there was established absence of previously determined pregnancy in 5.0-11.0\% of animals, that was the evidence of late embryonic death. When Surfagon was used in cows on day 5 after insemination frequency of embryonic death was decreased in 1.7 times or by $4.7 \%$ compare to the control group of cows. Combined using of Surfagon on day 5 and Ainil on day 11 promoted decreasing of embryonic death in 2.3 times or by $6.4 \%(p \geq 0,05)$.
\end{abstract}

Key words: Synchronization, fertility, Surfagon, Ainil, Ketoprofen.

\section{Introduction}

Nowadays only 30-50\% of inseminated cows actually calve (Macdonald et al., 2008; Norman et al., 2009; Dochi et al., 2010). Majority of pregnancy loses happens during the first 2-3 weeks after insemination, which is more higher compare to pregnancy terminations in more late terms (Walsh et al., 2011; Gutyj et al., 2017; 2018; Grymak et al., 2020; Roman et al., 2020). Fertility rate of heifers and cows with average milk production is from $90 \%$ to $100 \%$, but in high producing animals that are influenced by stress (for example due to hit) such rate can be reduced to 80\% (Sartori et al., 2010; Diskin et al., 2016). During the period from conceiving till reaching blastocyst stage by embryo only $45-55 \%$ of cows remain pregnant, compare to around $75 \%$ in heifers (Sartori et al., 2010; Walsh et al., 2011). Possibility of embryo development to blastocyst stage is determined by bunch of factors including quality of oocytes (Chebel et al., 2004; Sartori et al., 2010) and sperm (Saacke et al., 2000), post-partum period and condition of uterine environment (Lonergan et al., 2016).

Embryo, located in oviduct, produces Interferone-tau that slows down release of luteolytic Prostaglandin $F_{2 a}$ (Spencer et al., 2008). It is thought that ability of uterus to support development of embryo ensures pregnancy continuation (Lonergan et al., 2010). Microenvironment plays important role for embryo development (Rizos et al., 2002). It has been shown that Progesterone concentration (Diskin \& Morris, 2008; Lonergan et al., 2010), IGF insulin-like factors (Kusky \& Ye, 2012) and presence of pathogenic bacteria (Sheldon et al., 2006) influence embryo survival (Sartori et al., 2010; Walsh et al., 2011). Inability of maternal pregnancy recognition that leads to luteolytic is thought to be the main reason of embryo death in cattle (Diskin et al., 2008; Diskin et al., 2016). 
Progesterone concentration depends on quantity of lutein tissue and blood flow through liver, it can be regulated by increasing of lutein tissue and / or by restricting of Progesterone metabolism (Wiltbank \& Pursley, 2014). Low Progesterone concentration leads to reducing of pregnant cows with high productivity (Diskin et al., 2008). Increased concentration of circulating Progesterone right after conceiving promotes better embryo development (Satterfield et al., 2006; Carter et al., 2008). Conceiving during hit stress can be 10-20\% (Hansen \& Arechiga, 1999) comparing to 50\% in other year seasons. Continuous stress affects reproduction of cows (Rensis et al., 2015) due to quality reduction of oocytes and early embryos (Hansen, 2009). Oocytes can be damaged under influence of hit stress 105 days prior to ovulation (Torres-júnior et al., 2008) and after ovulation (Putney et al., 1988).

Non-steroidal anti-inflamatory preparations can slow down release of Prostoglandine $F_{2} a$ by uterine mucosa, consequently block luteolysis, and prevent early embryo death (Amiridis et al., 2009; Heuwieser et al., 2011). There is no one solid opinion about efficacy of non-steroidal anti-inflamatory preparations using for increasing of conceiving and prevention of embryonic death. Some researchers point on positive effect (Merrill et al., 2004; Merrill et al., 2007), others did not see it (Lucacin et al., 2010; Rabaglino et al., 2010) .

Thus, we checked the hypothesis regarding effect of combined using of preparations that promote Corpus Luteum creation and those that prevent luteolysis in embryonic period of pregnancy to keep gestation. The purpose of our research was to determine effect of Surfagon (day 5) and Ketaprofen (day 11) after insemination on conceiving and prevention of embryonic death in cows during the estrus synchronization depending on post-partum period in summer.

\section{Materials and Methods}

Experimental researches were conducted in conditions of dairy farms of Poltava and Kharkiv regions of Ukraine in summer of 2020. Estrus synchronizing in cows was started from 50-60 days after calving in Summer time. To prevent Infectious Rinotracheitis, Viral Diarrhea, Parainfluenza 3 in dairy herds cows were vaccinated with polyvalent vaccinations usually before or at the beginning of dry period. Before estrus synchronization trans-rectal sonographic examination was done in all cows to determine condition of uterus and ovaries. During the trial the herd of cows was divided in two groups depending on length of period from calving to estrus synchronizing. In the first group were cows up to 90 days after calving, in the second group - 91 and more days. Just to mention here, the second group also contained cows that were not able to be synchronized earlier because of reproductive organs pathology. In addition, there were animals among the second group that were synchronized the second time because of pregnancy absence after previous synchronization.

Cows were synchronized by "Ovsynch" protocol using following preparations: day 0 Surfagon was used in dose of $10 \mathrm{ml}$ (50 mcg); day 7 - Estrofan $2 \mathrm{ml}(500 \mathrm{mcg})$; day 9 - Surfagon $5 \mathrm{ml}$ (25 mcg); day 10 - insemination. Accordingly to the estrus synchronizing protocol the preparations were injected in evening at the same time. Cows were inseminated the next morning after the second injection of Surfagon accordingly to the protocol. After insemination cows were divided in three subgroups: two research groups and one control group. Cows of the first research subgroups were injected with Surfagon in dose of $10 \mathrm{ml}$ (50 mcg) on day 5 after insemination. Cows of the second research group were injected with $10 \mathrm{ml}$ (50 mcg) of Surfagon on day 5 after insemination and Ainil (active ingredient is Ketoprofen) in dose of $3 \mathrm{ml}$ on $100 \mathrm{~kg}$ of body weight on day 11 after insemination. Cows of control subgroups were injected at the same terms with isotonic solution of $\mathrm{NaCl}$ as a placebo.

Table 1. Scheme of conducted researches.

Sonographic examination of uterine condition and ovaries before estrus synchronizing Insemination of cows after estrus synchronizing by "Ovsynch" protocol

I group of cows before 90 days after calving
I III subroups

First pregnancy diagnostic in 30-32 days after insemination. Cows conceiving determination.

Second pregnancy diagnostics in 60-65 days after insemination. Determination of late embryonic death frequency. Notes. I subgroup - Surfagon 5-th day after insemination; II subgroup - Surfagon 5-th day, Ainil 11-th day after insemination; III subgroup placebo, control.

Pregnancy diagnostic by ultrasound scanner CTS-800 on day 30-32 after insemination was performed in all subgroups. Repeated pregnancy diagnostic was done in 60-65 days after insemination. Depending on pregnancy diagnostics results conceiving of cows was determined. In addition, comparing analysis was done regarding efficacy of prevention of late embryonic death in cattle.

\section{Results}

In general, conceiving of control groups with estrus synchronization was 35.9\%. However, conceiving rate of the second control group was higher by $10.2 \%(p \geq 0.05)$ compare to animals of the first control group.

In cows of first and second group with estrus synchronization and injection of Surfagon on day 5 after insemination, conceiving rate did not significantly differ from control group of cows, but in cows of the second group it was $5.8 \%$ higher. However, in cows of the second group, where Surfagon was used, conceiving was significantly higher by $16.1 \%$ ( $p \geq 0.01$ ) compare to these animals of the first group. 
Table 2. Conceiving of cows with estrus synchronization and using of GnRH and NSAID after insemination

\begin{tabular}{|c|c|c|c|c|c|c|}
\hline \multirow[b]{2}{*}{ Data } & \multicolumn{3}{|c|}{ First group } & \multicolumn{3}{|c|}{ Second group } \\
\hline & Synchronized & & $\%$ & Synchronized & & $\begin{array}{l}\text { ived } \\
\%\end{array}$ \\
\hline Surfagon, day 5 & 178 & 55 & 30,9 & 202 & 95 & $* \star 47,0$ \\
\hline Surfagon+Ainil days 5+11 & 195 & 75 & 38,5 & 199 & 107 & $* * 53,8 *$ \\
\hline Control & 203 & 63 & 31,0 & 187 & 77 & *41,2 \\
\hline Total & 576 & 193 & 33,5 & 588 & 279 & $\star * \star 47,4$ \\
\hline
\end{tabular}

Notes: ${ }^{*} p \geq 0.05 ;{ }^{* \star} p \geq 0.01$; ${ }^{* \star} p \geq 0.001$ - before figure compare to cows of the first group, after figure - to control group

Using of Surfagon on day 5 and Ainil on day 11 after insemination in cows of the first group with estrus synchronizing in 50-90 days after calving promotes increasing of their conceiving rate by $7.5 \%$ compare to animals of control group but there was no statistically detected difference, but in animals of the second group it increased by $12.6 \%$ ( $p \geq 0.01$ ) compare to cows of control group. In general, conceiving of trial cows of the first and the second group was $46.2 \%$ and was in $10.3 \%$ ( $p \geq 0.01$ ) higher than in control group animals.

Concluding received results it was possible to make a statement that synchronizing estrus in 50-90 days and 91 and more days after calving and Surfagon injection on day 5 after insemination promote increasing of conceiving rate of the cows in the second group by $5.8 \%$. Combined using of Surfagon on day 5 and Ainil on day 11 after insemination in cows of first group promote their conceiving by $7.5 \%$ compare to control animals of this group, and in the second group of cows - by $12.6 \%$.

During the second pregnancy diagnostic of cows in 60-65 days after insemination absence of previously detected pregnancy in $5.0-11.4 \%$ of animals was noted. For instance, using of Surfagon after insemination reduced the number of pregnant cows by $2.7 \%$, Surfagon and Ainil - by $2.3 \%$, in control group by $4.1 \%$.

Table 3. Prevention of late embryonic death in cows by different methods after insemination and synchronization

\begin{tabular}{|c|c|c|c|c|c|c|c|}
\hline \multirow[t]{2}{*}{ Data } & \multirow[t]{2}{*}{ Synchronization } & \multicolumn{2}{|c|}{$\begin{array}{c}\text { Pregnancy } \\
\text { diagnostics days } \\
30-32\end{array}$} & \multicolumn{2}{|c|}{$\begin{array}{c}\text { Pregnancy } \\
\text { diagnostics days } \\
60-65\end{array}$} & \multicolumn{2}{|c|}{ Embryonic death } \\
\hline & & & $\%$ & & $\%$ & & $\%$ \\
\hline Surfagon, day 5 after insemination & 380 & 150 & 39.5 & 140 & 36.8 & 10 & 6.7 \\
\hline $\begin{array}{l}\text { Surfagon day } 5 \text { and Ainil day } 11 \\
\text { after insemination }\end{array}$ & 394 & 182 & 46.2 & 173 & $43.9 *$ & 9 & $5.0 *$ \\
\hline Placebo & 390 & 140 & 35.9 & 124 & 31.8 & 16 & 11.4 \\
\hline Total & 1164 & 472 & 40.5 & 437 & 37.5 & 35 & 7.4 \\
\hline
\end{tabular}

Notes. * $p \geq 0.05$ - compare to cows of control group

In cows with the Surfagon was used on day 5 after insemination the frequency of embryonic death was reduced in 1.7 times or by $4.7 \%$ compare to control group of animals. Combined usage of Surfagon on day 5 and Ainil on day 11 promoted reduction of embryonic death in 2.3 times or by $6.4 \%$ ( $p \geq 0.05$ ). If in cows that were injected with Surfagon on day 5 after insemination frequency of embryonic death did not differ statistically from control group of animals, but in cows with combined using of Surfagon and Ketoprofen it was significantly lower $(p \geq 0.05)$.

\section{Discussion}

Conceiving of cows in control group with estrus synchronization was $35.9 \%$ and that was similar with other researches (Macmillan, 2010) obtained by using "Ovsynch" protocol. Conceiving rate of cows in the second control group was higher compare to the cows of the first control group, that could be explained by prolonged post-calving period (Azawi, 2008), reduction of bacterial microflora in uterus (Elkjær et al., 2013) and renewing of reproductive cyclicity after calving (Garcia-lspierto \& LópezGatius, 2014; Stangaferro et al., 2018). It is known that conceiving of cows with corpus luteum presence in ovary before estrus synchronization is higher than in non-cycling ones (Gumen \& Seguin, 2003; Gumen et al., 2003).

In cows of the first and second group with estrus synchronization and Surfagon injection on day 5 after insemination conceiving did not differ from control group cows. However, in cows of the second group were Surfagon was used conceiving rate was statistically higher, which pointed on increased efficacy of $\mathrm{GnRH}$ analog Surfagon in later post-calving period and that could be explained by the same reasons that were in control group of animals (Garcia-Ispierto \& López-Gatius, 2014; Stangaferro et al., 2018). Physiologic and hormonal changes that happen during reproductive cycle, promote renewing of uterine function and ovaries to optimum level for pregnancy process (Heppelmann et al., 2013).

Increasing of cows conceiving when combine using of GnRH and NSAID happen can be due to creation of additional corpus luteum and increased production of Progesterone under GnRH influence (López-Gatius et al., 2004) and slowing down of Prostoglandine F2 alpha release by uterine mucosa (Guilbault et al., 1987). It is known that NSAIDs can slowing down of Prostoglandine F2 alpha release by uterine mucosa through inhibiting of cyclooxygenases (COX) and prolong of reproductive cycle (Aiumlamai et al., 1990) because of saving of corpus luteum function (Odensvik et al., 1998). Using of non-steroid anti- 
inflamatory preparation leads to reduction of Prostoglandine metabolism (Geary, 2012), that points on slowing down of luteolysis (Odensvik et al., 1998), and therefore promotes increasing of conceiving (Rajkumar et al., 2010). Previous our researches and results obtained by other authors (Travetskii, 2017; Hüseyin Erdem) point on increased conceiving rate in cows when Ketoprofen is being used after insemination, but late embryonic death wiped out such difference (Şükrü Dursun, 2015), that possibly could be explained by non-specific (non-selective) action of Ketoprofen on cyclogeneses of both types and not effective slowing down of Prostoglandine F2 alpha release.

During the second pregnancy diagnostic of cows in 60-65 days after insemination absence of previously determined pregnancy was noted that was an evidence of late embryonic death and co-indicated with other authors results (Ledoux et al., 2014).

In cows, injected with Surfagon on day 5 after insemination the frequency of embryonic death was not statistically different compare to control group; in group of cows with combined usage of Surfagon and Ketoprofen it was significantly lower ( $p \geq$ 0.05). This can be explained by creation of additional corpus luteum after injection of GnRH analog - Surfagon (39) and slowing down of luteolytic Prostoglandine F2 alpha release by uterine mucosa as consequence of NSAD action on cyclooxygenases (Guilbault et al., 1987).

\section{Conclusions}

Combined using of GnRH and NSAID analogs after cows insemination by using "Ovsynch" protocol promotes conceiving increase due to early and late embryonic death reduction, particularly in animals after 91 days after the calving.

Further researches perspectives. Logically, influence of other preparations applied in different terms and combinations after the insemination could be studied.

\section{References}

Aiumlamai, S., Odensvik, K., Stabenfeldt, G., \& Kindahl, H. (1990). Regulation of prostaglandin biosynthesis with flunixin meglumine in the bovine species. J Vet Med A, 37(1), 16-22. doi: 10.1111/j.1439-0442.1990.tb00871.x

Amiridis, G. S., Tsiligianni, T., Dovolou, E., Rekkas, C., Vouzaras, D., \& Menegatos, I. (2009). Combined administration of gonadotropin-releasing hormone, progesterone, and meloxicam is an effective treatment for the repeat-breeder cow. Theriogenology, 72(4), 542-548. doi: 10.1016/j.theriogenology.2009.04.010

Azawi, O. I. (2008). Postpartum uterine infection in cattle. Animal Reproduction Science, 105(3-4), 187-208. doi: 10.1016/j.anireprosci.2008.01.010.

Carter, F., Forde, N., Duffy, P., Wade, M., Fair, T., Crowe, M. A., Evans, A. C., Kenny, D. A., Roche, J. F., \& Lonergan, P. (2008). Effect of increasing progesterone concentration from Day 3 of pregnancy on subsequent embryo survival and development in beef heifers. Reprod. Fertil. Dev., 20(3), 368-75. doi: 10.1071/RD07204

Chebel, R. C., Santos, J. E. P., Reynolds, J. P., Cerri, R. L. A., Juchem, S. O., \& Overton, M. (2004). Factors affecting conception rate after artificial insemination and pregnancy loss in lactating dairy cows. Anim. Reprod. Sci., 84(3-4), 239-55. doi: 10.1016/j.anireprosci.2003.12.012

de Rensis, F., Garcia-Ispierto, I., \& Lopez-Gatius, F. (2015). Seasonal heat stress: Clinical implications and hormone treatments for the fertility of dairy cows. Theriogenology, 84(5), 659-666. doi: 10.1016/j.theriogenology.2015.04.021

de S. Torres-Júnior, J. R., de F. A. Pires, M., de Sá, W. F., de M. Ferreira, A., Viana, J. H., Camergos, L. S. et al. (2008). Effect of maternal heat-stress on follicular growth and oocyte competence in Bos indicus cattle. Theriogenology, 69(2), $155-166$. doi: 10.1016/j.theriogenology.2007.06.023

Diskin, M. G., \& Morris, D. G. (2008). Embryonic and early foetal losses in cattle and other ruminants. Reprod. Domest. Anim., 43 (Suppl 2), 260-267.

Diskin, M. G., Waters, S. M., Parr, M. H., \& Kenny, D. A. (2016). Pregnancy losses in cattle: potential for improvement. Reprod. Fertil. Dev., 28(2), 83-93. doi: 10.1071/RD15366

Dochi, O., Kabeya, S., \& Koyama, H. (2010). Factors affecting reproductive performance in high milkproducing Holstein cows. J. Reprod. Dev., 56, S61-S65. doi: 10.1262/jrd.1056s61

Elkjær, K., Ancker, M. L., Gustafsson, H., Friggens, N. C., Waldman, A., Mølback, L., \& Callesen, H. (2013). Uterine bacterial flora in postpartum Danish Holstein dairy cows determined using DNA-based fingerprinting: Correlation to uterine condition and calving management. Animal Reproduction Science, 138(1-2), 39-48. doi: 10.1016/j. anireprosci.2013.01.016.

Garcia-Ispierto, I., \& López-Gatius, F. (2014). Effects of different five-day progesterone-based fixed-time Al protocols on follicular/luteal dynamics and fertility in dairy cows. Journal of Reproduction and Development, 60(6), 426-432.

Geary, T. W. (2012). Effects of adrenocorticotropic hormone and flunixin meglumine on pregnancy retention in beef cows. J Anim Sci, 90(1), 207-211. doi: 10.2527/jas.2010-3564

Grymak, Y., Skoromna, O., Stadnytska, O., Sobolev, O., Gutyj, B., Shalovylo, S., Hachak, Y., Grabovska, O., Bushueva, I., Denys, G., Hudyma, V., Pakholkiv, N., Jarochovich, I., Nahirniak, T., Pavliv, O., Farionik, T., Bratyuk, V. (2020). Influence of "Thireomagnile" and "Thyrioton" preparations on the antioxidant status of pregnant cows. Ukrainian Journal of Ecology, 10(1), 122-126. doi: 10.15421/2020_19

Guilbault, L. A., Thatcher, W. W., Drost, M., \& Haibel, G. K. (1987). Inflence of a physiological infusion of prostaglandin Finto postpartumcows with partially suppressed endogenous production of prostaglandins. Uterine and ovarian morphological responses. Theriogenology, 27, 931-946. 
Gumen, A., \& Seguin, B. (2003). Ovulation rate after GnRH or PGF2a administration in early postpartum dairy cows. Theriogenology, 60(2), 341-348. doi: 10.1016/s0093-691x(02)01372-9

Gumen, A., Guenther, J. N., \& Wiltbank, M. C. (2003). Follicular size and response to Ovsynch versus detection of estrus in noncyclic and cyclic lactating dairy cows. J Dairy Sci, 86(10), 3184-3194. doi: 10.3168/jds.s0022-0302(03)73921-6

Gutyj, B., Grymak, Y., Drach, M., Bilyk, O., Matsjuk, O., Magrelo, N., Zmiya, M., \& Katsaraba, O. (2017). The impact of endogenous intoxication on biochemical indicators of blood of pregnant cows. Regulatory Mechanisms in Biosystems, 8(3), 438-443. doi: 10.15421/021768

Gutyj, B., Grymak, Y., Hunchak, V., Mysak, A., Nazaruk, N., Brezvyn, O., Hariv, I., Shcherbatyy, A., Semeniv, B., Bushueva, I., Parchenko, V., \& Kaplaushenko, A. (2018). Preclinical searches of the preparation Thireomagnile. Ukrainian Journal of Ecology, 8(1), 688-695. doi: 10.15421/2018_267

Hansen, P. J. (2009). Effects of heat stress on mammalian reproduction. Philos. Trans. R. Soc. Lond. B. Biol. Sci., 364, 3341-3350.

Hansen, P. J., \& Arechiga, C. F. (1999). Strategies for managing reproduction in the heat-stressed dairy cow. J. Anim. Sci., 77 (Suppl 2), 36-50.

Heppelmann, M., Weinert, M., Brommling, A., Piechotta, M., Hoedemaker, M., \& Bollwein, H. (2013). The effect of puerperal uterine disease on uterine involution in cows assessed by Doppler sonography of uterine arteries. Animal Reproduction Science, 143(1-4), 1-7. doi: 10.1016/j.anireprosci.2013.11.003.

Heuwieser, W., Iwersen, M., \& Goetze, L. (2011). Efficacy of carprofen on conception rates in lactating dairy cows after subcutaneous or intrauterine administration at the time of breeding. Journal of Dairy Science, 94(1), 146-151. doi: $10.3168 / j d s .2010-3341$

Lonergan, P. (2010). Using basic approaches to address problems in dairy reproduction. In Smith, M. F., Lucy, M. C., Pate, J. L. and Spencer, T. J., eds. Reproduction in Domestic Ruminants, Anchorage, AK: Nottingham University Press, Nottingham, UK.

Lonergan, P., Fair, T., Forde, N., \& Rizos, D. (2016). Embryo development in dairy cattle. Theriogenology, 86, 270-277. doi: 10.1016/j.theriogenology.2016.04.040

López-Gatius, F., Santolaria, P., Yániz, J. L., \& Hunter, R. H. F. (2004) Progesterone supplementation during early fetal period reduces pregnancy loss in high-yielding dairy cattle. Theriogenology, 62, 1529-1535

Lucacin, E., Pinto-Neto, A., Mota, M. F., Acco, A., Souza, M. I. L., Alberton, J., \& Silva, A. V. (2010). Effects of flunixin meglumine on reproductive parameters in beef cattle. Anim. Reprod., 7(2), 75-79.

Macdonald, K. A., Verkerk, G. A., Thorrold, B. S., Pryce, J. E., Penno, J. W., McNaughton, L. R., Burton, L. J., Lancaster, J. A. S., Williamson, J. H. \& Holmes, C. W. (2008). A comparison of three strains of Holstein-Friesian grazed on pasture and managed under different feed allowances. J. Dairy Sci., 91(4), 1693-1707. doi: 10.3168/jds.2007-0441

Macmillan K. L. (2010). Recent advances in the synchronization of estrus and ovulation in dairy cows. J Reprod Dev., 56, S42S47.

Merrill, M. L., Ansotegui, R. P., Burns, P. D., MacNeil, M. D., \& Geary T. W. (2007). Effects of flunixin meglumine and transportation on establishment of pregnancy in beef cows. Journal of Animal Science, 85(6), 1547-1554.

Merrill, M. L., Ansotegui, R. P., Paterson, J. A., \& Geary, T. W. (2004). Effect of Flunixin Meglumine on Early Embryonic Mortality in Stressed Beef Females. Proceedings, Western Section, American Society of Animal Science, 55, 304-307.

Norman, H. D., Wright, J. R., Hubbard, S. M., Miller, R. H. \& Hutchison, J. L. (2009). Reproductive status of Holstein and Jersey cows in the United States. J. Dairy Sci., 92(7), 3517-3528. doi: 10.3168/jds.2008-1768

Odensvik, K., Gustafsson, H., \& Kindahl, H. (1998). The effect on luteolysis by intensive oral administration of flunixin granulues in heifers. Anim Reprod Sci, 50, 35-44.

O'Kusky J., Ye P. (2012). Neurodevelopmental effects of insulin-like growth factor signaling. Front. Neuroendocrinol. 33:2. 10.1016/j.yfrne.2012.06.002

Putney, D. J., Drost, M., \& Thatcher, W. W. (1988). Embryonic development in superovulated dairy cattle exposed to elevated ambient temperatures between Days 1 to 7 post insemination. Theriogenology, 30, 195-209.

Rabaglino, M. B., Risco, C. A., Thatcher, M. J., Lima, F., Santos, J. E., \& Thatcher, W. W. (2010). Use of a five-day progesteronebased timed $\mathrm{Al}$ protocol to determine if flunixin meglumine improves pregnancy per timed Al in dairy heifers. Theriogenology, 73(9), 1311-1318.

Rajkumar, R., Singh, S. K., Agarwal, S. K., Mahmood, S., \& Shankar, U. (2010). Effect of selective COX-2 inhibitor on conception rate, progesterone and PGFM profile in buffalo (Bubalus bubalis). J Appl Anim Res, 38, 209-212.

Rizos, D., Ward, F., Duffy, P., Boland, M. P., \& Lonergan, P. (2002). Consequences of bovine oocyte maturation, fertilization or early embryo development in vitro versus in vivo: implications for blastocyst yield and blastocyst quality. Mol. Reprod. Dev., 61, 234-248.

Roman, L., Broshkov, M., Popova, I., Hierdieva, A., Sidashova, S., Bogach, N., Ulizko, S., \& Gutyj, B. (2020). Influence of ovarian follicular cysts on reproductive performance in the cattle of new Ukrainian red dairy breed. Ukrainian Journal of Ecology, 10(2), 426-434

Roman, L., Sidashova, S., Danchuk, O., Popova, I., Levchenko, A., Chornyi, V., Bobritska, O., \& Gutyj, B. (2020). Functional asymmetry in cattle ovaries and donor-recipients embryo. Ukrainian Journal of Ecology, 10(3), 139-146. doi: 10.15421/2020_147

Saacke, R. G., Dalton, J. C., Nadir, S., Nebel, R. L., \& Bame, J. H. (2000). Relationship of seminal traits and insemination time to fertilization rate and embryo quality. Anim. Reprod. Sci., 60-61, 663-677. doi: 10.1016/S0378-4320(00)00137-8

Sartori, R., Bastos, M. R., \& Wiltbank, M. C. (2010). Factors affecting fertilisation and early embryo quality in single- and superovulated dairy cattle. Reprod. Fertil. Dev., 22(1), 151-158. doi: 10.1071/rd09221 
Satterfield, M. C., Bazer, F. W., \& Spencer, T. E. (2006). Progesterone regulation of preimplantation conceptus growth and galectin 15 (LGALS15) in the ovine uterus. Biol. Reprod., 75, 289-296.

Sheldon, I. M., Lewis, G. S., LeBlanc, S., \& Gilbert, R. O. (2006). Defining postpartum uterine disease in cattle. Theriogenology, 65, 1516-1530.

Sire effect on early and late embryonic death in French Holstein cattle (2015). Ledoux D1, Ponsart C2, Grimard B1, Gatien J2, Deloche MC2, Fritz S2, Lefebvre R3, Humblot P2. Animal, 9(5), 766-774. doi: 10.1017/S1751731114003140

Spencer, T. E., Sandra, O., \& Wolf, E. (2008). Genes involved in conceptus-endometrial interactions in ruminants: insights from reductionism and thoughts on holistic approaches. Reproduction, 135(2), 165-79. doi: 10.1530/rep-07-0327

Stangaferro, M. L., Wijma, R., Masello, M., Thomas, M. J., Giordano, J. O. (2018). Extending the duration of the voluntary waiting period from 60 to 88 days in cows that received timed artificial insemination after the Double-Ovsynch protocol affected the reproductive performance, herd exit dynamics, and lactation performance of dairy cows. Journal of Dairy Science, 101(1), 717-735.

Şükrü Dursun (2015). The effect of ketoprofen and flunixin meglumine treatment and pregnancy rate in brown swiss nonlactating cows and heifers. Thesis of Doctoral Dissertation. Erdem University.

Travetskii, M. O., Kraevsky, A. Y., Musiienko, Yu. V. (2017). Prevention of embryonic mortality in cows. Scientific Bulletin of LNUVMBT named after S.Z. Gzhitskiy, 19(77), 200-203.

Walsh, S. W., Williams, E. J., \& Evans, A. C. O. (2011). A review of the causes of poor fertility in high milk producing dairy cows. Anim. Reprod. Sci., 123(3-4), 127-38. doi: 10.1016/j.anireprosci.2010.12.001

Wiltbank, M. C., \& Pursley, J. R. (2014). The cow as an induced ovulator: timed Al after synchronization of ovulation. Theriogenology, 81(1), 170-185. doi: 10.1016/j.theriogenology.2013.09.017

Citation:

Kraevskiy, A.Y., Sokolyuk, V.M., Travetskiy, M.O., Chekan, O.M., Musiienko, Y.V. (2020). Application of Surfagon and Ketaprofen for increasing fertility and preventing embryonic death in cows after insemination. Ukrainian Journal of Ecology, 1044), 159-164.

(cc) EY This work is licensed under a Creative Commons Attribution 4.0. License 